e-ISSN: 2721-3013, p-ISSN: 2721-3005

DOI: https://doi.org/10.38035/jafm.v1i1

Received: 10 February 2020, Revised: 23 Ferbruary, Publish: 10 March 2020 https://creativecommons.org/licenses/by/4.0/

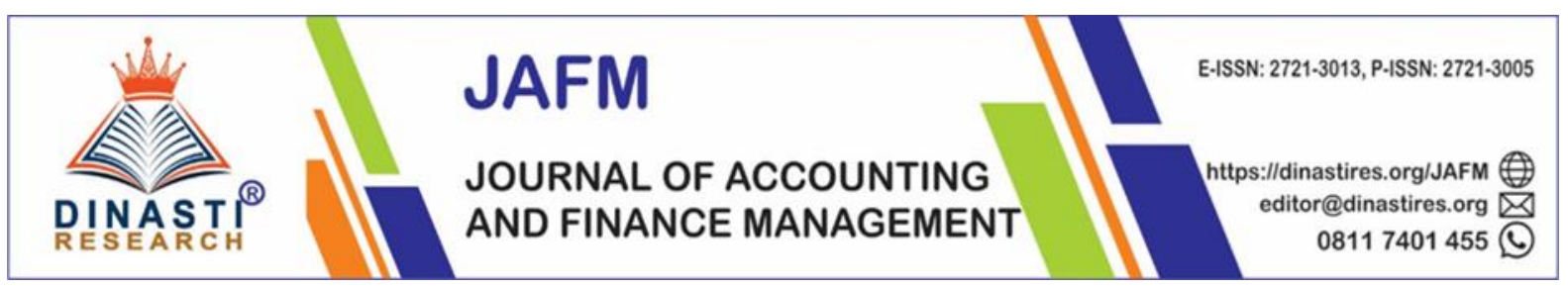

\title{
Implementation of Digital Marketing to Increase Satisfactionand Impact on the Image of Banking PT. Bank Central Asia Tbk
}

\author{
Mohamad Arfiman Yosep ${ }^{1 *}$, Yoyo Sudaryo ${ }^{2}$, Astrin Kusumawardani ${ }^{3}$, Nandan Limakrisna ${ }^{4}$ \\ ${ }^{1)}$ Indonesian College of Economics Building, Faculty of Economics, Jl. Soekarno-Hatta No.448, \\ Bandung 40266, Indonesia, arfiyosep777@ gmail.com \\ ${ }^{2)}$ Indonesian College of Economics Building, Faculty of Economics, Jl. Soekarno-Hatta No.448, \\ Bandung 40266, Indonesia \\ ${ }^{3)}$ Indonesian College of Economics Building, Faculty of Economics, Jl. Soekarno-Hatta No.448, \\ Bandung 40266, Indonesia \\ 4) Universitas Persada Indonesia, Jakarta, Indonesia
}

Corresponding Author: Mohamad Arfiman Yosep ${ }^{1}$

\begin{abstract}
The banking industry currently wants to provide the best service to the public because of the many bank expansion that has just sprung up but already offers a lot of banking convenience services. This begins with the application of digital marketing that makes it easy for customers to make transactions. Digital marketing is very easy because transactions can be done only through smartphones or other devices. Some banks have services such as internet banking, mobile banking, SMS banking, and customers can now create new accounts using only their smartphones. This makes digital marketing a new service prima donna in providing services to the public in the banking world in Indonesia. The research method used in this research is descriptive and verification research. A descriptive method is a method in examining the status of a group of people, the status of an object, a set of conditions, a system of thought, or a class of events in the present
\end{abstract}

Keywords: Digital Marketing, Satisfaction, Image

\section{INTRODUCTION}

Marketing is the spearhead of a company and becomes very important, especially in the banking sector. Industrial competition in the banking world is getting tougher, especially the development of technology that acts as the development of the banking world. The banking industry currently wants to provide the best service to the public because of the many bank expansion that has just sprung up but already offers a lot of banking convenience services. This begins with the application of digital marketing that makes it easy for customers to make transactions. Digital marketing is very easy because transactions can be done only through smartphones or other devices. Some banks have services such as internet banking, mobile banking, SMS banking, and customers can now create new accounts using 
only their smartphones. This makes digital marketing a new service prima donna in providing services to the public in the banking world in Indonesia. KPIs are used to assess internal online activity, according to (Chaffey \& Smith, 2013) among others are:

1. Unique visitors (Unique visitors), i.e. number of individual, separate visitors to the site (usually counted per month).

2. Conversion rates to different goals (The conversion rate becomes a different destination),

3. i.e. the percentage of visitors converted to customers (or consumers).

4. A total number of sessions or visits to a web site, that is the total number of sessions or visits to the website.

5. Repeat visits (Repeated visits), i.e. the average number of visits per individual. The total number of sessions divided by the number of unique visitors. Update your site more often and people will come more often. Cookies can help track repeat visits. Remember to always get permission before entering a cookie into someone else's PC.

6. Duration (Duration), which is the average amount of time visitors spend on the site (but it must be kept in mind in some areas of the site, such as online sales or customer service, the duration must be minimized). A similar measurement is the number of pages viewed per visitor.

7. Most popular pages or most popular products (The most popular pages or the most popular products), this indicator can be identified by looking at which pages attract the most traffic and the longest duration.

8. Subscription rates (Subscription level), i.e. the number of visitors who subscribe to services such as opt-in email and newsletters.

9. Churn rates (Outgoing rate), i.e. the percentage of subscribers leaving or unsubscribing (after getting an email).

10. Clickthrough rates (CTR) (click rate), i.e., from banner ads or web links from other sites.

11. Engagement and social media ROI (Social media involvement and ROI), i.e. new social contacts, spreading the conversation, the polarity of the talks, and sales influenced by social media. All of the above KPIs can be calculated and used as an objective, and are always assessed.

From the theoretical basis according to Smith and Chaffey (2013), we as researchers limitonly to 5, namely:

1. Engagement Website,

2. Social Engagement,

3. Clickthrough rates (CTR),

4. Conversion rates to different goals (CR), and

5. Duration.

The still high number of payment systems via ATMs is certainly a PR for banks to prepare new strategies so that online transaction payments can be made easily. The growth of e-commerce is increasing in line with the increase in internet users and public trust in the security of electronic transactions. With online banking transactions, users now have more confidence in the security of their transactions. This response certainly shows a positive value for banks to continue to develop online banking products so that users continue to trust the bank. For the above phenomenon, The researcher is interested in researching with the title "Implementation of Digital Marketing Against Customer Headquarters and Its Impact on Banking Image of PT. Bank Central Asia Tbk ".

a. Research Background

1. Image of PT. Bank Central Asia Tbk is still not good. This is due to the lack of customer satisfaction for the digital marketing services of PT. Bank Central Asia Tbk.

2. Customer satisfaction, customers are not satisfied with the digital marketing services of PT. Bank Central Asia Tbk viewed through 5 indicators (Website Engagement, Social 
Engagement, Clickthrough rates (CTR), Conversion Rates (CR), and Duration), especially convenience in accessing a website can affect the image of PT. Bank Central Asia Tbk.

3. Implementation of digital marketing (Website Engagement, Social Engagement, Clickthrough rates (CTR), Conversion Rates (CR), and Duration) which need to be measured to what extent their effect on digital customer satisfaction.

4. Customers are not satisfied when accessing the website of PT. Bank Central Asia Tbk because it has an inadequate level of speed

5. Customers feel the need for digital transactions on various products that are not available or incomplete.

6. Digital services through the website of PT. Bank Central Asia Tbk sometimes does not respond quickly to customer requests.

7. Digital services through the website of PT. Bank Central Asia Tbk provides less nimble responses to customers in the event of a disruption.

b. Research Question

1. How is the description and analysis of the implementation of digital marketing PT. Bank Central Asia Tbk.

2. How is the description and analysis of customer satisfaction PT. Bank Central Asia Tbk.

3. How is the image and analysis of PT. Bank Central Asia Tbk.

4. How does the influence of digital marketing implementation on PT. Bank Central Asia Tbk.

5. How does the influence of digital marketing implementation on the banking image of PT. Bank Central Asia Tbk.

6. How does customer satisfaction influence the banking image of PT. Bank Central Asia Tbk.

7. How does the effect of digital marketing implementation on customer satisfaction and its influence on the banking image of PT. Bank Central Asia Tbk.

\section{LITERATURE REVIEWS}

Etymologically the word management is taken from ancient French, which is management, which means the art of organizing and implementing. Management can also be interpreted as an effort to plan, coordinate, organize, and control resources to achieve goals efficiently and effectively.

According to (Terry \& Rue, 2010) Management is a typical process that consists of the actions of planning, organizing, mobilizing, and controlling to determine and achieve goals through utilization. So it can be concluded that management is a process that contains POAC, namely Planning, Organizing, Actuating and Controlling, or in Indonesian known as planning, organizing, directing, and controlling by resources so that results can be achieved effectively and efficiently.

From some management functions, it can be understood that management starts with planning (planning), organizing (organizing). The next step after implementing the planning and control functions can be formulated as a process of determining what needs to be achieved namely standards, what is being implemented is implementation, assessing implementation, and when necessary making improvements, so that implementation is by the plan that is in line with standards.

According to (Daryanto, 2011) The company's success in running its organization is inseparable from the success of the marketing team's performance, in every marketing company it is always the spearhead for a profitable company, by sharing the company's strategy it will be run to achieve profitability. 
Marketing according to the American Marketing Association (AMA) quoted by (Dhruv \& Levy, 2014)explains that marketing is: "Marketing is the activity, sets of institutions, and processes for creating, capturing, communicating, delivering, and exchanging offerings that have value for customers, clients, partners, and society at large" which means "Marketing is an activity, organizing institutions, processes for creating, communicating, delivering, and exchanging offerings that have value for customers, clients, and society in general ".

According to Law No.7 of 1992 concerning banking which was later refined to Act No.10 of 1998 concerning banking, explaining that there are 2 types of banks, namely:

1. Commercial Banks according to Law No.10 of 1998, namely banks that carry outbusiness activities conventionally and / or based on sharia principles in their activities providing services in payment traffic. Business activities that can be carried out by commercial banks are:

a. Collecting funds from the public in the form of deposits in the form of time deposits, savings, funds or other forms equivalent;

b. Issue a letter of acknowledgment of debt;

c. Receive payments for securities bills and make calculations with or among third parties.

2. Bank Perkreditan Rakyat according to Law No.10 of 1998, namely as a bank carrying out conventional business activities and or based on sharia principles in which its activities do not provide payment traffic services. The tasks of the People's CreditAgency include:

a. Collecting funds from the public in the form of deposits in the form of time deposits, savings, funds, or other similar forms.

b. Give credit to small entrepreneurs and households.

c. Provide financing for customers based on profit sharing principles by the provisions stipulated in Government Regulations.

According to (Kotler \& Keller, 2013) said that E-Marketing is a way of marketing that is done through computers (and other electronic goods such as laptops, gadgets) by using a means of communication that aims to reduce marketing costs and increase the effectiveness of marketing efforts. E-marketing is a process that utilizes. Digital marketing or digital marketing is another term that is similar to internet marketing.

Objective Research

1. The implementation of digital marketing that is used is only limited to 5, namely (Website Engagement, Social Engagement, Clickthrough rates (CTR), Conversion Rates (CR), and Duration) PT. Bank Central Asia Tbk.

2. PT. Bank Central Asia Tbk.

3. Banking image of PT. Bank Central Asia Tbk.

\section{RESEARCH METHOD}

The research method used in this research is descriptive and verification research. A descriptive method is a method in examining the status of a group of people, the status of an object, a set of conditions, a system of thought, or a class of events in the present(Sugiyono, 2012). The purpose of this descriptive study is to make a systematic, factual, and accurate description, picture, or painting of the facts, properties, and relationships between the phenomena investigated. The verification method is: "The nature of verification research wants to test the truth of a research hypothesis carried out through data collection in the field" (Arikunto, 2013) So, in this research, we will test the truth about the effect of Digital Marketing implementation on customer satisfaction and its impact on the image of banks at PT. Bank Central Asia Tbk. 


\section{REFERENCES}

Arikunto (2013). Research Procedure: A Practical Approach.

Chaffey, D., \& Smith, P. (2013). E-Marketing Excellence. Planning and Optimizing Your Digital Marketing. Abingdon: Routledge.

Daryanto (2011). Marketing Management: Course Study. Bandung: One Nusa. Dhruv, G., \& Kotler, P., \& Keller, K. (2013). Marketing Management. Jakarta: Erlangga.

Levy, M. (2014). Marketing, Fourth Edition. New York: Graw-Hill.

Sugiyono (2012). Qualitative Quantitative Research Methods and R\&D. Bandung: Alfabeta. Terry, G., \& Rue, L. (2010). Fundamentals of management. Jakarta: Rough Earth. 